\title{
Field observations from the Aquila, Italy Earthquake of April 6, 2009
}

T. ROSSETTO $^{1}$, N. PEIRIS ${ }^{2}$, J.E. ALARCON ${ }^{3}$, E. SO ${ }^{4}$, S. SARGEANT $^{5}$, M. $^{\circ}$ FREE $^{6}$, V.SWORD-DANIELS ${ }^{6}$, D. DEL RE ${ }^{2}$, C. LIBBERTON $^{7}$, E. VERRUCCI ${ }^{1}$, P. SAMMONDS ${ }^{8}$, J. FAURE WALKER ${ }^{8}$

${ }^{1}$ Department of Civil and Environmental Engineering, University College London, Gower Street, London, WC1E 6BT, UK. (Address for Correspondence)

${ }^{2}$ Risk Management Solutions Ltd., 30 Monument Street, London, EC3R 8NB, U.K.

${ }^{3}$ AIR Worldwide Ltd., New London House, 6 London Street, London, EC3R 7LP, U.K.

${ }^{4}$ Cambridge Architectural Research Ltd., 25 Gwydir Street \#6, Cambridge, CB1 2LG

${ }^{5}$ British Geological Survey, Murchison House, West Mains Road, Edinburgh, EH9 3LA, UK.

${ }^{6}$ Arup, 13 Fitzroy Street, London, W1T 4BQ, UK.

${ }^{7}$ Sellafield Ltd., Sellafield, Seascale, Cumbria, CA20 1PG, U.K.

${ }^{8}$ Department of Earth Science, University College London, Gower Street, London, WC1E $6 B T, U K$.

\section{Abstract}

On April 6, 2009 an earthquake of Magnitude $6.2\left(\mathrm{M}_{\mathrm{w}}\right)$ struck the Abbruzzo region of Italy causing widespread damage to buildings in the city of L'Aquila and surrounding areas. This paper summarizes field observations made by the Earthquake Engineering Field Investigation Team (EEFIT) after the event. The paper presents an overview of seismological and geotechnical aspects of the earthquake as well as a summary of the observed damage to buildings and infrastructure. A brief overview of the earthquake casualties is also reported.

Key words: L’Aquila Earthquake, Field Survey, Strong Ground Motion, Building Damage

\section{Introduction}

An earthquake hit the Abruzzo region of Italy on the $6^{\text {th }}$ April 2009 at 3:32am local time. This earthquake had a moment magnitude of $6.2 \mathrm{M}_{\mathrm{W}}$ and a shallow focal depth ( 8-9 km, according to the Istituto Nazionale di Geofisica e Vulcanologia, INGV, 2009: 
www.ingv.it ). The epicentre of the earthquake is located $95 \mathrm{~km} \mathrm{NE}$ of Rome and 10km West of L'Aquila. L'Aquila is the administrative capital of the region of Abruzzo (Figure 1) and has a population of more than 68,000 . The earthquake intensity was determined to reach IX EMS-98 (see Section 4.2) in the proximity of Aquila. In total the earthquake killed 305 people, injured over 1,500 people and made approximately 70,000 people homeless (Protezione Civile, 2009 and PreventionWeb, 2010). The total economic cost of damage to buildings is estimated to be 4Bn Euro (PreventionWeb, 2010), whilst the insured loss to be in the range 260-400M Euro (AIR Worldwide). Additional details on total and insurable losses are described by Alarcon et al. (2010).

Figure 1 Historical and instrumental events with magnitudes larger than 5.0 recorded in Central Italy since 1005 A.D. Light colour events correspond to shallow events whilst dark colour earthquakes correspond to deep events (Source: Henni et al. 1998)

The close proximity of the causative fault to the town of L'Aquila resulted in the collapse of many historical masonry buildings in its town centre, including the town hall, National museum of Abruzzo, and many major historic churches. In addition, the earthquake affected reinforced concrete structures of more modern construction. In particular, the “Hotel Duca degli Abruzzi” and ahall of residence of L’Aquila University collapsed. Smaller villages within a distance of about $50 \mathrm{~km}$ of the causative fault were also severely damaged. The broad range of affected buildings is representative of construction types in many European countries, making this earthquake of particular interest to the European earthquake engineering community.

The UK Earthquake Engineering Field Investigation Team (EEFIT) decided to mount a reconnaissance mission to the Abruzzo region following the earthquake. This paper presents some of their findings. The paper starts with a description of the event with reference to the region's historical seismicity and tectonics. It then presents field observations of geotechnical features, damage and performance of buildings, hospitals, schools, industrial facilities and transportation structures. Finally a brief discussion is presented on casualties and their relationship with the observed building damage. Further images from the EEFIT Team field mission can be seen on the Virtual Disaster Viewer (www.virtualdisasterviewer.com). This viewer development is an ongoing project supported by EEFIT and other international earthquake reconnaissance teams. It allows 
the visualisation of the geo-referenced photos taken by the team, with pre- and postearthquake satellite images for the affected areas as well as mapped faults.

\section{The L'Aquila Earthquake}

\subsection{The L’Aquila Event and Seismic Hazard in the Central Apennines}

The $\mathrm{M}_{\mathrm{W}}$ 6.2 L'Aquila earthquake occurred in the Central Apennines (see Table 1 for epicenters published for the earthquake). The Central Apennines is a zone of relatively high seismic activity and is located within the Africa-Eurasia collision zone, although the region itself is undergoing north-east - south-west extension (e.g. Pace et al., 2006). There are numerous high-angle normal faults oriented roughly north-west - south-east showing several hundreds of meters of displacement (Cello et al., 1997). Many of the largest earthquakes that have occurred in the Italian peninsula have normal faulting mechanisms indicating extension perpendicular to the trend of the Apennine belt.

The earthquake was a shallow (c. $10 \mathrm{~km}$ ) normal faulting event. The focal mechanism published by the Instituto Nazionale di Geofisica e Vulcanologia (INGV) indicates that the nodal planes are oriented roughly north-west - south-east and therefore consistent with the regional tectonic setting. The aftershock distribution is consistent with rupture on the south-westerly dipping nodal plane. The earthquake was preceded by a prolonged swarm-like sequence of events in the same area that began in December 2008 (see Figure 1). The extent to which this sequence increased the probability of the mainshock occurring is unknown. Numerous aftershocks have occurred and are located in three clusters around the largest earthquakes of the sequence (the mainshock, 7 April (5.3 $\mathrm{M}_{\mathrm{L}}$ ), 9 April $\left.\left(5.1 \mathrm{M}_{\mathrm{L}}\right)\right)$. The zone of aftershocks is oriented approximately north-east - southwest and the mainshock delineates the western edge of this zone.

Historically, Central Italy has experienced many destructive earthquakes (see Figure 1); most recently, the Umbria-Marche earthquake sequence of September 1997, approximately $100 \mathrm{~km}$ to the north-west of the 2009 event, killed 11 people and caused significant damage (Spence et al. 1998). Notable historical moderate magnitude (c. $\mathrm{M}_{\mathrm{W}}$

6.5-6.7; Pace et al., 2006) earthquakes that have affected the Abruzzo region include 9 September 1349, 26 November 1461 (intensity X on the Mercalli Cancani Sieberg scale at L'Aquila) and the 1703 sequence (intensity XI MCS for the Norcia-L'Aquila region) 
(Pace et al., 2002). In terms of its felt effects, the 2009 earthquake strongly resembles the 1461 event (Rovida et al., 2009).

Seismic hazard in the L’Aquila region has been thoroughly investigated (e.g. Romeo and Pugliese, 2000; Pace et al., 2006; Akinci et al., 2009) and the horizontal peak ground acceleration (PGA) hazard level is found to be in the order of $0.25 \mathrm{~g}$ for a return period of 475 years. Deaggregation analysis by Akinci et al. (2009) indicates that the 475 year PGA hazard at L'Aquila is largely controlled by large earthquakes ( $\mathrm{M}_{\mathrm{W}}$ 6.5-6.7) on faults oriented parallel to the dominant structural trend. The L'Aquila fault is interpreted to contribute most to the 475 year return period PGA hazard. Thus the 6 April 2009 L’Aquila earthquake could be considered as a “design event” for 475 year return period and consequently the performance of buildings and other facilities in response to this event could be used to assess the seismic design and construction practice in the region.

\subsection{Strong Ground Motion}

Both INGV and the Protezione Civile Nazionale (PCN) operate strong motion networks in the area. INGV also deployed a network of temporary sensors following the mainshock. Table 2 presents the peak ground accelerations (PGA) recorded by the RAN (Rete Accelerometrica Nazionale) network of PCN within $50 \mathrm{~km}$ from the epicentre.

Figure 2 shows the PGA values as a function of the Joyner-Boore $\left(\mathrm{R}_{\mathrm{jb}}\right)$ metric distance(Abrahamson \& Shedlock, 1997) for the entire RAN network (56 recordings). In this figure the data is separated according to site condition at the recording station using the soil classification system of Eurocode 8 (EC8, 1998). For comparison purposes Figure 2 also shows the PGA values given by the Akkar and Bommer (2007) ground-motion predictive equations (GMPEs). The Akkar and Bommer (2007) predictions are presented for rock, stiff soil and soft soil site conditions, the equation parameters were set to normal faulting and the ground-motion predictions were adjusted from the geometric mean to the largest component following Beyer and Bommer (2006). The latter adjustment is required since the RAN data is for the larger of the two horizontal components. Figure 2 indicates that in general terms the GMPEs under-predict the recorded PGA values at distance less than $10 \mathrm{~km}$ and over-predict the recorded PGA values at distances greater than $10 \mathrm{~km}$ irrespective of ground conditions. 
Figure 2 Recorded PGA values from the entire RAN network classified according to EC8 site classification and compared with the Akkar and Bommer (2007) GMPEs for three site classes (rock, stiff soil and soft soil)

Very high values of PGA $(0.675 g)$ were recorded near L'Aquila town centre (Station AQV), see Table 2. In a study undertaken prior to the April 2009 earthquake, De Luca et al. (2005) found evidence of significant ground motion amplification near L'Aquila at station AQK at low to medium frequencies (around $0.6 \mathrm{~Hz}$ ) which they interpreted to be related to the presence of thick (c. $250 \mathrm{~m}$ ) sedimentary deposits within the valley. Ameri et al. (2009) made the same observation with regard to the April 2009 event data. L'Aquila is located within a broad valley aligned approximately NW-SE and ground conditions within the valley comprise alluvium, underlain by lacustrine deposits and bedrock at depth. On the valley sides, the ground conditions comprise slope deposits of conglomerate and breccias underlain by older limestone bedrock. Ground motion site response amplification is therefore expected within the valley region with corresponding relatively higher levels of damage at locations within the valley than on the valley slope regions (see section 4.2).

Figure 3 Comparison of EC8 Type 1 acceleration response spectra (for 475 year return period) with the spectra from the recorded horizontal ground motions at the GSA station at $8.6 \mathrm{~km}$ from the source (left) and at the CNL station at $20 \mathrm{~km}$ from the source (right). Please note that the vertical scales are different on each plot

A comparison between the acceleration response spectra from recorded ground motions and the elastic acceleration spectra of Eurocode 8 (EC8 Type 1, 475 year return period) is shown in Figure 3. The records from two sites on rock have been selected; one located within the near-source region station (GSA) at $8.6 \mathrm{~km}$ from the source and the other (CNL) at $20 \mathrm{~km}$, both using the $\mathrm{R}_{\mathrm{jb}}$ distance metric. The original recordings were processed using a bandpass Butterworth filter and using linear base line correction. Although it is recognised that identification of significant trends is not possible based only on two recordings it can be seen from Figure 3 that the short period ground motions in the near-source area (GSA station) were higher than those indicated by the elastic spectra and those at medium distances (CNL station) were lower than the elastic spectra. These near field, short period ground motions are likely to have had the largest effect on low-rise buildings (up to four storeys). 


\section{Geotechnical Observations}

\subsection{Fault Related Surface Rupture}

A zone of tension cracks was observed at Paganica and Tempera. The predicted fault surface rupture model indicates the strike and dip of the fault plane to be 143 and 60 degrees respectively and is predicted to occur approximately $9 \mathrm{~km}$ northwest of the INGV epicentre. The tension cracks observed may be consistent with a normal faulting model with rupture initiating at a depth of approximately $10 \mathrm{~km}$, as indicated by the hypocentral depth and focal mechanism of the earthquake (see Section 2.1) .

The observed tension cracks extended over approximately $1 \mathrm{~km}$ with individual cracks measured over 5 to $20 \mathrm{~m}$ in length. A $700 \mathrm{~mm}$ diameter high pressure water pipe, which crossed the alignment of the tension cracks at Paganica ruptured during or soon after the earthquake, and was under repair at the time of the EEFIT visit to the area (see Figure 4). A total of 49 measurements of the tension cracks at 6 sites (a grassy slope, 2 tarmac roads, a cement floor, a soil bed and a concrete pavement) show the fault slip vector azimuth, plunge and strike of the fault is 219, 57 and 110 degrees respectively. An average of 50mm (maximum 90mm) horizontal and 50mm vertical displacement was measured at the surface, corresponding to 70 to $100 \mathrm{~mm}$ of surface slip. At Tempera cracking was observed crossing a tarmac single lane road at several locations. Individual crack lengths could only be traced across the width of the road for 3 to $4 \mathrm{~m}$ with maximum displacement in the order of 50mm horizontally and 50mm vertically but more typically 5-10 mm horizontally and 5-10mm vertically. At Tempera a set of 8 sub-parallel cracks were observed at roughly equal intervals over $200 \mathrm{~m}$. These findings are consistent with preliminary results found using

InSar (http://www.esa.int/esaMI/Space_Engineering/SEMF780PFBG_1.html\#subhead1) , focal mechanisms of the main shock and with the regional tectonics which is dominated by northeast-southwest extension. The InSar shows the maximum subsidence occurred near the village of Onna, where some of the worst damage was observed.

Tension cracks were also observed to cross a concrete retaining wall, concrete floor slabs and exterior walls of reinforced concrete frame modern residential buildings (see Figure 5). The tension cracks have been categorised into three categories (following the mapping 
practice followed by geologists from the Italian Civil Protection working in Paganica, who met with EEFIT in the field and provided us with a map of the cracks they had measured):

- tectonically induced (cracks cross green-field and man-made features but does not display orientation control by the man-made features),

- structurally controlled (cracks follow alignment of man-made features such as building joints, pavement joints or tile boundaries), and

- settlement related (cracks located on steep slopes where slope displacement is interpreted to be largely controlling the displacement).

Creep displacement appears to be ongoing on some of the features. For example, in Paganica, the EEFIT team measured a 1 degree rotation in a crack in a retaining wall in a two day interval. It was noted in the field that extensometers have been installed to monitor the movement on the cracks by the Italian Civil Protection.

Figure 4 Slope failure caused by washout associated with a burst water main (pipe to the right in the photograph) and other services at Paganica caused by fault rupture. Slope debris can be seen 100-150m downslope.

Figure 5 Paganica: tension cracks passing through stone paving and single storey building (left) and tension crack in the hillside above the town centre (right).

\subsection{Liquefaction}

No direct evidence of liquefaction was observed. Tension cracks and lateral spreads adjacent to the Aterno river and to an artificial lake (Lago Sinizzo) were observed but it was not possible from field evidence to determine whether these features had occurred as a result of liquefaction or by failure of a low shear strength cohesive soil layer.

\subsection{Earthquake Induced Slope Instability}

The region is surrounded by mountainous topography with steep slopes and there is evidence of ongoing pre-earthquake slope instability on steep slopes throughout the region. However, small rock falls, interpreted to have been caused by the earthquake, were also observed. At Fossa a rock fall of approximately $300 \mathrm{~m}^{3}$ occurred from the steep rock slopes above the town, with individual boulders of 1 to $2 \mathrm{~m}^{3}$ travelling down into the town and damaging buildings and cars. Another large rock fall was observed on the road 
between Paganica and Camarda. This rock fall appeared to have blocked the road but had been cleared by the time of fieldwork. Typical smaller rock falls from natural and cut slopes were observed at many locations, for example a $3 \mathrm{~m}^{3}$ rock planar failure on a cut slope adjacent to Lake Sinizzo (Lago Sinizzo) as shown in Figure 6.

Figure 6 Lake Sinizzo: a small rock planar failure from $\sim 4 \mathrm{~m}$ high cut slope (left) and slumping in fill around the edges of the lake.

Slumping of the man-made ground around Lake Sinizzo was observed (Figure 6). Tension cracks were observed around the edge of the lake in the man made deposits around the lake. The individual tension cracks could be traced for 5 to $20 \mathrm{~m}$ and formed arcuate features around the lake edge. The majority of the landsliding at this location was restricted to the opening of tension cracks and lateral movement of 0.5 to $1 \mathrm{~m}$ with movement toward the lake. Tension cracks could be measured to extend to greater than $1 \mathrm{~m}$ depth where the cracks were infilled with water. In some cases the sliding toward the lake was more extensive with horizontal travel distances of 5 to $10 \mathrm{~m}$ in two cases. The failure volumes in these two cases were in the order of 30 to $40 \mathrm{~m}^{3}$.

\subsection{Effects of the L’Aquila Earthquake on Buildings}

The damage observed from the L'Aquila earthquake varied substantially depending on the location, building typology, age of construction and condition. In order to gain a better understanding of the seismic vulnerability of construction in this area, this section first provides a brief description of the development of seismic codes in Italy, and of design base shear values for structures in the L'Aquila region. An overview of the damage observed in the field by the EEFIT Team is then presented and damage to different structure typologies illustrated in more detail.

\subsection{Brief Overview of the Development of the Italian Seismic Code}

The first seismic code in Italy was developed in 1909 following the 1908 Messina Earthquake. This code contained guidance on siting of buildings, good construction practice, and limited the heights of buildings (Fralleone and Pizza, 2000). In 1916, quantitative lateral design loads were introduced that equaled $12.4 \%$ of the structure weight $\left(\mathrm{W}_{1}\right)$ applied at the ground storey and $16.6 \%$ applied to storeys above ground. The structure dead loads were also increased by $50 \% \mathrm{~W}_{1}$ to account for the vertical component of ground motion (Fralleone and Pizza, 2000). The first seismic hazard map of Italy was 
developed in 1928 (Reggio Decreto n. 431) and divided Italy into two zones: areas of high and low seismicity. However, these zones only included those areas that had been hit by earthquakes since 1908 (De Marco et al. 2000). In July 1933, Regio Decreto n.29, (referred to in Fralleone and Pizza, 2000) the vertical seismic loading was reduced to $40 \% \mathrm{~W}$ and lateral seismic loads relaxed to $10 \% \mathrm{~W}$ uniformly distributed along the structure height in zone 1 and 7\%W in zone 2. Furthermore, the live loads included in the structure weight calculations were reduced to 0.3 of their total value, hence $W$ (used to signify the sum of the building dead load plus 0.3 of the live load) is smaller than previous $W_{1}$ (Fralleone and Pizza, 2000). The 1933 code was subsequently updated several times through a series of Government Decrees and Circulars. Of special notice is Law no.64 of 1974 (Legge 2 Febbraio 1974 n.64) and subsequent Governmental Decree in March 1975 (DM 3.3.75 N.40), which for the first time introduce the concept of response spectra to the seismic design of buildings in Italy and was the first seismic code to cover the whole Italian territory. It set up a framework for future code updates and code enforcement. Within the 1974 code an equivalent lateral load method is used for the calculation of the seismic loads and a working stress approach is used to design structures. The total horizontal seismic load $F$ is calculated from Equation 1 below.

$$
\begin{aligned}
& F=C \cdot R \cdot I \cdot \varepsilon \cdot \beta \cdot W \\
& C=\frac{S-2}{100} \\
& T_{0}=0.1 \frac{H}{\sqrt{B}}
\end{aligned}
$$

Where, $C$, the numerical coefficient of seismic intensity is calculated according to Equation 2 from the seismicity coefficient $S$. The 1974 code set out the framework for a new seismic zonation, and in 1984 a new seismic zonation was introduced that divided Italy into 4 zones ranging from no to high seismicity (see Figure 8). This map was based on felt intensities, included data to distinguish between different tectonic environments and general criteria for classifying districts (De Marco et al. 2000). The seismicity factor $S$ takes a value of $0,6,9$ or 12 corresponding to zones $4,3,2$ and 1 of the Italian seismic hazard map, respectively. The affected area in the Aquila Region is within Zone 2 (S=9) in both the maps available in 1974 and 1984 (Figure 7). In Equation 1, I and $\varepsilon$ are the importance and foundation coefficients, respectively, which are assumed to equal 1 for structures of normal importance founded on firm soil. $\beta$ is the structural coefficient, which takes a value of 1.0 for most structures and for moment resisting frames. $W$ is the weight 
of the structure, calculated from the combination of the permanent dead loads and 1/3 of the live loads. $R$ is the response coefficient, which takes a unit value for structures with natural periods below $0.8 \mathrm{~s}$, or $\left(0.862 / T_{0}^{2 / 3}\right)$ otherwise. $\mathrm{H}$ and $\mathrm{B}$ are the height and width of the building in meters, respectively. For low to mid-rise (less than 8 storey) RC moment resisting frame buildings of ordinary importance, the design base shear is therefore $7 \% \mathrm{~W}$ in Zone 2. It is not possible to understand from the code the assumed ductility of buildings designed to this code nor the design pga (or what return period it corresponds to), although the code states that for dynamic analysis a pga of $0.1 \mathrm{~g}$ and $0.07 \mathrm{~g}$ can be used for zones 1 and 2, respectively. These reflect the values of normalised lateral load proposed in the 1933 code.

Figure 7 Seismic Hazard maps of Italy (a) In 1975, dark and light orange areas indicate Zone 1 and Zone 2, respectively. Source: De Marco et al. (2000) (b) In 1984. Source: INGV (2009) (c) In 2003, for 475 year return period. Source INGV (2009).

Despite new seismic codes being issued in 1986 (DM 24.1.86) and 1996 (DM 16.1.96), the seismic load calculation for buildings in the earthquake affected areas of the L'Aquila region essentially remained unchanged as the horizontal load calculation equation and seismic classification of these areas remained the same. In the 1996 code, limit state design is allowed but weighting factors are introduced in order to achieve the same design level as from working stress design (Gruppo di Lavoro, 2003). The main change implemented in the 1996 code (and 1997 circular n.65/97) is a criterion that requires the overdesign (increase in strength of 40\%) of elements in storeys above and below any storey with large openings or where a significant change in stiffness occurs between stories. This criterion is introduced to avoid soft-storey failure but does not constitute a “capacity design” criterion.

In 2003 a "new generation” code (Ordinanza PCM n. 3271) was introduced that mirrored the development of the European seismic code Eurocode 8 (EC8, 1998). Capacity design is introduced into the code and the base shear equation is the same as that in Eurocode 8 and is reproduced in Equation 4.

$$
\begin{aligned}
& F=S_{d}\left(T_{1}\right) \cdot \lambda \cdot W \\
& T_{1}=C \cdot H^{3 / 4}
\end{aligned}
$$


Where, $S_{d}\left(T_{1}\right)$ is the design spectral acceleration, evaluated using the same response spectrum equations as in Eurocode 8 (not reproduced here). $H$ is the height of the structure in meters and $C$ is a coefficient which takes the value of 0.085 for steel frame structures, 0.075 for reinforced concrete frame structures and 0.05 otherwise. $\lambda$ is a coefficient that takes a value of 0.85 if the structure is 3 or more storeys high and if $T_{1}<$ 2Tc (where Tc is the period defining the end of the spectrum plateau, which value depends on the site soil classification), or a value of 1.0 otherwise. $W$ is the weight of the structure, calculated from the combination of the permanent dead loads and a portion of the live loads (approximately 1/3). The behaviour factor equation is given by:

$$
q=q_{0} \cdot K_{R} \cdot K_{D}
$$

Where, $q_{0}$ is the basic behaviour factor which has different values for different types of structural type. For example, $q_{0}=5.85$ for a multi-storey, multi-bay moment resisting RC frame. $K_{R}$ is a regularity coefficient that takes a value of 1 or 0.8 for structures that are regular or irregular in elevation, respectively. $K_{D}$ is a coefficient that represents the ductility class and takes a value of 1 or 0.7 for high and medium ductility classes, respectively.

A major revision of the seismic zonation of Italy also accompanies the 2003 building code. This was based on a full probabilistic seismic hazard assessment using an up to date catalogue of earthquake events (Gruppo di Lavoro 2004). The map, reproduced in Figure 7(c), shows the seismic zones and corresponding range of pga values for anchoring the code response spectrum. For a 475 year return period the pga anchor values are $0.35 \mathrm{~g}$ and $0.25 \mathrm{~g}$ for Zones 1 and 2, respectively. For a low-rise ( 3 storey) regular, reinforced concrete, moment resisting frame, of normal importance sited on rock in Zone 2, the 2003 code produces design base shears of $9.1 \% \mathrm{~W}$ and $13 \% \mathrm{~W}$ for high $(\mathrm{q}=5.85)$ and medium ( $q=4.1$ ) ductility classes, respectively. These values decrease for taller RC frame buildings e.g. are 5.3\%W and 7.5\%W, respectively for 8 storey buildings. The 2003 code does not specify the behaviour factor for a low-ductility class, so for comparison with the 1974 code a behaviour factor of half the high ductility value (i.e $q=2.93, K_{D}=0.5$ ) is assumed, which produces base shear values of $10 \% \mathrm{~W}$ and $18 \% \mathrm{~W}$ for a regular 8 and 3 storey RC moment resisting frame, respectively. This shows a1.4 to 2.6 fold increase in the design values of the earlier code. Despite the fact that buildings designed to the earlier code are designed using working stress methods, (hence a direct comparison of design loads with the ultimate limit state design loads of the 2003 code cannot be made), this level of 
increase would suggest that buildings designed to the 1974 code, especially low-rise structures, would be severely damaged or collapse in the epicentral region of the L'Aquila earthquake. The latter being typical of a 475 year return period event in the region (see Section 2.2).

\subsection{Overview of Building Stock in the Affected Area}

The area affected by the L'Aquila earthquake presents a heterogeneous mix of building types, particularly in the residential building stock. The different ages of the buildings explains this heterogeneity, with different forms and types of construction being in favour at different times of the growth of the population in the area. Reinforced concrete replaced masonry as the favoured load bearing material in the second half of the $20^{\text {th }}$ century, but the majority of the reinforced concrete buildings date from after 1970. Typically most towns or cities have a historic centre with more recent areas of development on the outskirts. This applies both to L'Aquila and its satellite towns and villages, where even the smaller settlements maintain a small historic centre, of narrow streets and low rise buildings, with new construction on the outskirts (e.g. Paganica). The villages in the hills, such as Fossa, have not experienced more recent expansion and the building stock is older.

In L’Aquila the juxtaposition between older centre and the more recent outskirts is evident, and age of buildings can be mapped almost concentrically, with a large proportion of buildings within the walls dating to the baroque era when L'Aquila was rebuilt after a destructive earthquake in 1703. Immediately outside the old city walls, buildings date from the $20^{\text {th }}$ century and further afield the new developments, such as those in Scoppito, and the outer ring, to the 1990’s and post 2000.

The Italian census data from the 2001 ISTAT Census reports percentages of buildings in different ages and forms of construction (see Table 3). The statics show that while the proportion of RC buildings in L'Aquila is comparable to the national average, the age range of the building stock is more recent, indicating that more buildings than the national average were built when more stringent seismic codes were in force.

\subsection{Overview of Building Damage Observations}


Figure 8 shows the locations surveyed by EEFIT in and around L'Aquila with a summary estimate of the EMS-98 intensity (Grünthal, 1998) in each city based on damage surveys carried out by EEFIT. These surveys were not comprehensive macro-seismic surveys and were carried out in a small time window, sometimes for only part of the village/town visited, with the purpose of gaining an overall understanding of the extent of the affected area. These are reproduced in Figure 9 and Table 4. For the purpose of the EMS-98 intensity survey, masonry residential buildings have been assumed to be vulnerability Class B and reinforced concrete buildings vulnerability Class C, except for in locations of new buildings (post 2003) where reinforced concrete buildings were assigned to vulnerability Class D. Damage states were assigned according to the EMS scale DS0 to DS5. The intensity survey for the locations not listed in Table 4 was carried out assigning an aggregated percentage of buildings to each damage state. Figure 8 shows that there appears to be more damage in the valley region of L'Aquila than the region of sloping topography on either side of the valley, and more damage east of L'Aquila compared to west of L'Aquila. This observation is consistent with the site amplification effects expected from the softer soil in the valley East of L’Aquila as described in section 2.2.

Figure 8 Surveyed locations in L'Aquila and estimated EMS-98 intensity. “A” indicates the location of the epicentre. Dots with two colours indicate the intensity lies between two values. The values in rectangular call-outs are the recorded PGA values at sites in and near Aquila (as reported in Table 4).

Figure 9 Graphs of damage frequencies observed in several affected cities, based on small surveys by EEFIT (see also Table 4).

It can be seen from the damage statistics reported in Table 4 that the pattern of damage is such that the historic stone masonry buildings without any restoration and retrofitting experienced substantial damage ranging from extensive to collapse. Those buildings with steel ties and reinforced concrete (RC) ring beams performed relatively better with damage mainly ranging from slight to moderate, with only some extensive damage. Reinforced Concrete (RC) construction generally performed well compared to masonry buildings. The following sub-sections provide an overview of the performance of these building classes as observed by the EEFIT Team. It brings together observations made in 
different areas in order to generalize performance. An overview of damage to industrial facilities, schools and hospitals is also provided.

\subsection{Damage to Reinforced Concrete Buildings}

The main RC buildings observed in the affected region consist of 2 to 4 storey residential buildings and multi-storey (up to 8 storeys) residential and office buildings. All these structures are moment resisting RC frames with either hollow clay brick infill or concrete block infill. The floor is composed of beam and block construction, where small RC precast beams with steel reinforcement in the bottom, support hollow clay blocks over which wire mesh and concrete screed is placed. Roofs often consisted of the same construction as the flooring, and sometimes of RC slab. The vast majority of RC buildings observed are interpreted to have been built in the period between the 1974 code and 1996 building codes and hence do not adopt capacity design principles. As stated in section 4.1, a comparison of the design base shear for such buildings with those expected from the L'Aquila event (assumed typical of the 475 year return period event, see section 2.2), should have resulted in the severe damage or collapse of a large proportion of these buildings near the earthquake source. In practice, in the majority of towns in the earthquake source region, and in L'Aquila itself, the reinforced concrete frames were mostly undamaged with varying levels of damage to the infill panelling only (e.g. Figure 10). This makes the buildings repairable but the extent of infill damage sometimes precluded immediate re-occupancy. Structural damage was rare, meaning that most frames resisted the earthquake loads elastically. This is inconsistent with the expected behaviour based on design load comparison. This "extra strength" may be due to a number of features relating to the structure (e.g. overdesign or positive contribution of infill panels) or the earthquake strong ground motion (e.g. low amplification over structural frequencies of interest for the taller buildings).

Figure 10 RC frame building in Aquila Centre with severe damage to infill but intact structural frame.

Some RC buildings did collapse. Examples of these are three observed soft-storey failures in Pettino (2) (see Figure 11) and San Gregorio (1). In all these cases failure was precipitated by irregular stiffness in elevation. Poor detailing of reinforcement in connections was evident as well as lack of confinement in columns. These structures date from the mid 1980s and although contained a degree of seismic design, did not include 
capacity design and pre-date the limitations posed by the 1996 code on stiffness irregularities between stories in elevation (see section 4.1).

Figure 11 Three storey RC frame with soft-storey failure in Pettino.

Three major failures to RC frames were also observed by EEFIT in L'Aquila Centre: the Hotel Duca degli Abruzzi (Figure 12), the Aquila University halls of residence, and a 5 storey (with basement) residential building. In all cases the buildings were interpreted to have been constructed in the late 1970's. In each case a section of the building underwent total collapse. The Hotel Duca degli Abruzzi seems to have failed through a combination of soft-storey mechanism formation exacerbated by sloping topography. Poor detailing of column reinforcement was observed with smooth reinforcing bars and inadequate confinement steel (Figure 12). In the case of the halls of residence, it was not possible to identify the failure mechanism due to site clearance for rescue. However, from exposed connections and rubble, smooth reinforcement was again present. In the residential building one of the main problems is seen to be the lack of transverse reinforcement in columns and connections. Columns seem to have failed in compression before beam yielding. Although the design loads are expected to have been exceeded, the collapse mechanisms observed indicate a lack of robustness and redundancy of members and poor general design that is worrying.

Figure 12 Hotel Duca degli Abruzzi in Aquila (left) view of the hotel (right) detail of failed column.

Few modern RC buildings were observed but where seen were undamaged or sustained slight non-structural damage. An example of this was observed above the town of Paganica. A series of modern 3 storey residential houses were virtually undamaged by the strong ground shaking, despite being located near Paganica old town centre that suffered 90\% damage to its masonry buildings. Figure 13 shows a three storey RC Frame with clay full brick infill that was built in 2001. Evidence of strong ground shaking was observed through falling objects in the house as well as radiator pull-out from wall and wardrobe pounding. However, the house suffered only minimal hairline cracking between infill and frame. 
Figure 13 RC building with clay brick infill, constructed in 2001, residential two-storey located on the hillside above Paganica. Building undamaged

\subsection{Masonry Buildings (Residential and Historical)}

Masonry construction is the predominant building type for residential housing in the affected area (see Table 3). The building material for the walls is local stone, with clay fired bricks used above openings and interspersed in the wall matrix. Within a single building, a range of masonry materials can be used: cut stone, rubble stone, clay tiles and bricks. In larger buildings the wall construction can exceed 500mm in thickness and the common form of wall construction called "a sacco" is used. "A Sacco" construction means that the walls are formed by two external wythes (skins) of cut stone and the gap between is filled with mortar and rubble pieces of smaller dimension. The true make-up of the masonry walls is often hidden by a render finish.

Floor structures vary significantly between adjacent and apparently similar buildings. Masonry vaulted ceilings are common, spanning in one or two directions in the older buildings (Figure 14a). Other floor constructions include timber joisted floors, and more modern floors with concrete precast beams with clay hollow bricks spanning up to $1 \mathrm{~m}$ between adjacent beams and sustaining a concrete screed layer reinforced with a steel wire mesh. A variation of the latter sees the precast concrete beams substituted with steel I-beams. Roofs are predominantly pitched at around 15 degrees and are timber-beam with clay tile covering, or in more recent constructions RC pitched floors are used that consist either of RC slabs or RC beam and block construction similar to that used in floors (Figure 14b).

Seismic loads for the design of masonry buildings have followed those of reinforced concrete. But in the case of masonry, height limitations are also imposed by the Italian codes. For example in the L’Aquila region (Zone 2) unreinforced masonry structures are allowed to be of maximum height 11m (1996 code). Given the strong observed ground motion in the epicentral region it is unsurprising that so much damage resulted in masonry structures. High frequencies of severe damage and collapse were observed relatively far from the earthquake source. Some of the higher than expected levels of damage may be due to soil amplification of the ground motion but the majority of damage is interpreted to be due to poor connections, flexible floor and roof structures and lack of maintenance in the buildings. 
Figure 14 Building typologies (left) a major collapse opposite the University Building in L'Aquila showing the typical masonry wall construction and vaulted floor construction; (right) Building in Poggio di Roio with concrete slab roof. Falling render shows how the presence of concrete roof and slabs exists with stone masonry wall loadbearing walls

Historical buildings (e.g. churches and cathedrals) were surveyed in L’Aquila and several of the small towns visited by the EEFIT team. The quality of construction in these buildings was greater than that observed in the masonry residential buildings. Walls adopted larger cut stone, however the same "a sacco" technique of building was used for walls. Corner stone quoins were always observed in these buildings, whereas they were not always present in residential masonry buildings. Furthermore, strengthening measures were commonly seen.

Over the centuries, some interventions have been made to maintain and improve the stability of masonry structures (residential and historical) with techniques that are common in the whole of Italy and Southern Europe. The introduction of iron, then steel, ties and braces to restrain the walls from horizontal movement is a common method of strengthening that was observed in the affected areas, especially in the built up areas. Requirements that ties should be inserted in masonry structures deemed not to have sufficient connections and earthquake resistance was also introduced in the Italian seismic code revision of 1986. However, it is unclear whether this code requirement was actively enforced or if homeowners took it on themselves to add the ties. Although no statistics were obtained, many instances but not uniform use of ties was observed. Some homeowners have carried out strengthening that involves upgrading the floor through the addition of a layer of reinforced concrete, achieving a composite action with the existing floor, and achieving a floor deck with enhanced stiffness and connection with the external walls. Others have substituted timber floors with reinforced concrete slabs cast in-situ or pre-cast. RC ring beams were also observed on occasion at the roof level of masonry buildings. In the towns of Poggio Picenze and San Gregorio, several houses were seen to have had wire mesh and concrete screed also added to external masonry walls to enhance their strength.

Figure 15 Severely damaged masonry church in Paganica 
Masonry buildings without seismic provisions are inherently vulnerable to ground shaking, and those in the L'Aquila region are no exception. Masonry buildings in rural areas, with only one or two storeys suffered the greatest number of collapses. The poor quality mortar, masonry workmanship and materials all compound to cause the failure of the walls panels. The more extreme examples of this are the collapses in the village of Onna (see Section 4.2). Cross-iron ties, when present at all floor levels and in both horizontal directions, helped prevent or reduce out-of plane failure of external walls. The collapse of internal floors was commonly observed when concrete beam-clay hollow block floors (or steel beam-clay hollow block) floors were used, caused by the unseating of the supporting floor beams from the walls. Failure was more common (e.g. in Paganica) where no steel wire mesh was used to reinforce the concrete screed floor surface. In massive buildings and monuments of L'Aquila, the thickness of the walls at lower levels meant that the tension forces that initiate collapse of masonry were not observed. As a result damage occurred at the higher levels of the buildings, so parapets, top corners, and church timpani were the most severely damaged (Figure 15). A large proportion of buildings also suffered wide spread cracking, in the form of X-cracks due to in-plane shear forces or cracking at the corners of openings.

\subsection{Industrial Facilities}

There are two industrial estates in the L'Aquila area: a few kilometres West of the City lies the Pile Nucleo Industriale and to the East of the city, off the SS17 the larger Bazzano industrial estate. Industrial sheds are built with precast RC frame and precast planks. There were no major collapses in these structures. Only two cases of cladding collapse were observed. It should be noted that the EEFIT survey in these cases was not extensive and was carried out from the roadside. Accounts from a local consulting engineer indicate that up to $20 \%$ of the structures suffered minor damage in the form of collapse to cladding panels. The EEFIT team was able to carry out a detailed visit to the Dompé pharmaceutical company in the Pile Nucleo Industriale estate where the worst reported damage to industrial buildings occurred. The building construction is in situ concrete frame and precast planks or T-beams. The major form of structural damage consists of short-column failure (Figure 16). The total cost of repair works is initially estimated to exceed $€ 10$ million.

Figure 16 Short-column failure in Dompe’ Pharmaceutical Plant 
Interruption of production can be a significant contributor to the financial losses incurred by the industrial sector. Production in the Dompe' plant was not expected to recommence until the $7^{\text {th }}$ of May (one month after the earthquake). A pharmaceutical company in L’Aquila, which employs more than 300 people, was not expecting to reach full production until mid May (one and a half months after the earthquake). In these cases, damage to the facilities, structural and non-structural, was the cause of production disruption. In many other instances, production at the plants was hindered due to the workforce having been evacuated from their homes and living in temporary shelters, in some cases hours from the workplace.

\subsection{Schools and Hospitals}

L'Aquila hospital is the main and largest medical centre in the area. Construction of the hospital was completed in 2000. The hospital is formed by several main blocks most of which are 4-storeys in height and some of which present irregular shapes in elevation and plan. The EEFIT damage assessment was carried out from the perimeter of the hospital buildings as access to the structure interior was not permitted. The majority of L'Aquila hospital buildings are made of reinforced concrete moment-resisting frames, with either concrete block masonry or hollow clay brick infill. The areas mostly affected were observed in the northern side of the hospital where the top walls of the façade on the entrance collapsed (see Figure 17), and shear cracks were observed along infill walls. Vertical sheet steel strips were observed to bridge between structural beams at the external face of infill walls. These seem to have been put in place in order to prevent out of plane displacement of infill block work (Figure 17). However, the extent and frequency of this type of reinforcement could not be assessed. The RC frames seemed to have performed well with no significant cracks being observed in columns or beams, though cracks were observed on a ground floor column on a northern side building. The dimensions of the top beam on the northern entrance seem to be larger than those of the columns. On closer inspection of the blocks towards the western end of the hospital complex, lack of cover was observed in the structural beams with transverse beam reinforcement observable through the concrete cover. Moreover, initial signs of reinforcement corrosion were observed.

The hospital remained completely shut at the time of the EEFIT mission, with a camp set out in the grounds with medical facilities for the treatment of patients. A local newspaper “Il Centro"” reported (on the $22^{\text {nd }}$ April 2009) that the hospital would be opened in a very limited capacity on the $27^{\text {th }}$ April, i.e. 21 days after the earthquake. Online sources (e.g. 
TgCom, YouReporter), published three months after the quake, reported the hospital to be in partial use, with a capacity of 160 patients.

Figure 17 L'Aquila hospital: (left) view of buildings to the North of hospital complex. Note that the infill walls on the top floor of the entrance collapsed. (right) Detail of reinforcement of an infill wall by means of steel strips

The EEFIT team observed several schools in the affected area. These were of both masonry and reinforced concrete construction. All schools observed by EEFIT suffered less than grade 3 damage (EMS-98). In the schools observed, this was due to their recent construction, limited height or the implementation of some level of strengthening. For example, a one-storey primary school in Onna built in 2004 was observed to have sustained no damage despite all other buildings in the town being severely damaged (Figure 18). A school in Lucoli that sustained slight damage was instead observed to have brackets and mesh placed at gutter level to stop any loosened roof tiles from falling (Figure 19). The local newspaper "Il Centro" reported (on the $22^{\text {nd }}$ April 2009) that of the 294 schools in Abruzzo 209 were open, 78 were closed and 12 were partially open. 2709 children below the age of 18 were living in temporary accommodation. On the $4^{\text {th }}$ August, the Italian Government stated (Source: Tg@bruzzo) that all schools in Abruzzo with nonstructural damage, had been assessed, repaired and had returned to full functionality. Buildings extensively damaged would not be occupiable at the start of the new term, but are being temporarily replaced by 29 precast structures, 22 of which are in the city of L’Aquila.

Figure 18 Primary school in Onna. One storey RC frame building with infill, which sustained no damage despite severe damage observed to all buildings in the surrounding area.

Figure 19 Elementary school in Aquila. RC frame building with infill, which sustained slight damage. 


\subsection{Observations on Casualties}

In total, there were 305 reported fatalities and over 1,500 injuries. Table 5 shows the distribution of fatalities amongst affected towns, indicating the predominant construction type and observed intensity.

The lethality rates seen in Table 5 follow the observed intensity values, with higher lethality rates corresponding to larger intensities and larger proportions of building collapse. Overall, this event exhibited relatively low lethality rates, especially when compared to the M6.8 Avezanno earthquake of 1915 where around 32,000 people died and over $93 \%$ of the population of 11,000 of Avezzano city perished. The epicentre was further away from dense population centres and the event was smaller, but two further factors are thought to contribute to the low lethality rate. Firstly, in the two months prior to the 6 April event the area had been subject to a series of small earthquakes. In the town of Paganica, (where approximately 90\% of the masonry houses were damaged but the official number of fatalities is 7), interviewed survivors said they had slept in their cars after feeling an earthquake tremor 4 hours before the main event. Secondly, the area contains many weekend (second) homes for people living in Rome and other large Italian cities, and as the earthquake happened in the early hours of Monday morning these people would have already left the region. Furthermore, the time of the L'Aquila event meant that there were no mass gatherings in old religious buildings or in schools in the area. The damage to religious buildings noted during the EEFIT mission (section 4.5) would have caused mass casualties, similar to those seen after the Irpinia earthquake of 1980 (de Bruycker et al. 1985).

Alexander (2009) carried out a study on the causality statistics of the event. He reports that more females than males died in the earthquake and, as would be expected, there was a high occurrence of deaths in people aged over 70. As suggested in a study by Osaski and Minowa (2001) into the factors associated with earthquake deaths in the Great Hanshin-Awaji (Kobe) earthquake, mortality increases with age, disability and the degree of destruction of the structure in which the victims are trapped since the elderly are less mobile and more fragile. However, Alexander (2009) also reports a disproportionate number of deaths (20\% of the total) amongst 20 to 29 year olds. L'Aquila is a university city housing nearly 23,000 students. Apart from the collapse of the reinforced concrete Casa dello Studente in L'Aquila, Alexander (2009) explains that students are more likely 
to rent cheaper accommodation in worse maintained houses that were more vulnerable to damage in this earthquake.

Search and rescue efforts were carried out by a mixture of national servicemen, the Red Cross, fire brigade, volunteers and cavers. In total, the number of people participating in search and rescue totaled 11,000 after 48 hours. According to the Red Cross based at Coppito very few people were found alive. Most people were either able to escape on their own, with the help of neighbours or sadly died. This is in line with what has been seen in earthquake events where masonry collapses dominate e.g. Bhuj, 2001, Bam, 2003 and Kashmir, 2005 (So, 2009). In some earthquakes like Bam, there is evidence that asphyxiation resulting from the dust and fine material released when buildings collapsed has contributed to deaths of its occupants (Hatamizadeh et al., 2006). The collapse mechanism of masonry buildings also creates fewer voids for occupants and reduces chances of survival. Rescue efforts may have focused in reinforced concrete frame buildings where voids are more likely.

According to the Civil Protection, there are a total of 62,200 people displaced from their homes in this event of which 28,500 are living in tented villages (http://www.protezionecivile.it/, 21/5/2009). Camps were set up by the $7^{\text {th }}$ April (the day after the event) around the affected area. Eight camps were set up in L'Aquila city and located in stadiums, sports grounds and at the train station. The largest camp housed 4,500 people and was situated in the army barracks at Piazza D’Armi. Camps were also set up outside majorly affected towns in the L'Aquila district. These camps were equipped with medical facilities, central catering and sanitation provisions. Around 24,300 displaced people were housed in hotels near the Adriatic coast and 9,400 found accommodation with friends and family. A policy of "evacuate all” was adopted by the Civil Protection, until all buildings are inspected by qualified engineers with earthquake engineering experience. Over 1500 engineers were deployed for this purpose, and were instructed to prioritise the assessment of lightly damaged buildings (with the aim of quickly re-housing people), and buildings of strategic importance. Experts from the Ministry of Cultural Heritage were also sent to inspect churches and historical buildings in the area. 


\subsection{Conclusions}

This paper presents a summary of the observations made by the United Kingdom Earthquake Field Investigation Team (EEFIT) during an eight day reconnaissance of areas affected by the 6 April 2009 L’Aquila Earthquake.

Each earthquake presents a different set of findings that enhance the understanding of buildings and infrastructure response to the effects of ground shaking. This earthquake has also provided material to support research in a number of aspects of earthquake engineering science:

- This paper has shown that some of the RC buildings closest to the epicenter performed above the design criteria. This is an area that deserves further research to enhance the understanding of "as-built" structures, and flag the buildings at risk more accurately.

- Damage to L’Aquila's main hospital gives engineers the opportunity to better understand the implications to serviceability of non-structural damage to key infrastructure.

- The collapse of multiple RC buildings in and around L'Aquila was a stark reminder of the lethality rate of RC buildings and the presence of vulnerable examples in the European building stock. Diagnostic research of the causes of these collapses will increase the ability to identify the buildings at risk and design mitigating solutions.

- The older and prevalent masonry building stock suffered widespread damage and served as a reminder of the vulnerability of this form of construction. It was encouraging to see a relatively widespread use of strengthening measures. There was evidence of the success the steel and iron ties had in preventing collapse, and the resulting body of knowledge from this event on how ties perform can help engineers demonstrate the cost and life-saving effectiveness of introducing them extensively in existing vulnerable buildings.

The L’Aquila earthquake will also be remembered as the most damaging earthquake in Western European and Italy since the Messina and Reggio Calabria event of 1908 to affect an urban environment. The impact of the damage on the dense urban setting exacerbates the impact on the economy and the ability to carry out repair work safely. The citizens of L'Aquila deserve the full attention of the engineering, planning and 
architectural community to bring their city back its pre-earthquake modest grandeur and bustle.

\section{Acknowledgements}

Participation of T. Rossetto, S. Sargeant, E. Verrucci and E. So in the EEFIT mission was funded by the Engineering and Physical Sciences Research Council (EPSRC), who are thanked for their support. Risk Management Solutions, AIR Worldwide, Sellafields Ltd and Arup are thanked for sponsoring the participation of their employees.

\section{References}

Abrahamson N.A. and Shedlock K.M., 1997. Overview. Seis. Res. Lett. 68 (1), 9-23. Akkar S. and Bommer J.J., 2007. Prediction of elastic displacement response spectra in Europe and the Middle East. Earthquake Engineering and Structural Dynamics 36, $1275-$ 1301.

Akinci, A., Galadini, F., Pantosti, D., Petersen, M., Malagnini, L., and Perkins, D., (2009). Effect of time dependence on probabilistic seismic-hazard maps and deaggregation for the Central Apennines, Italy, Bull. Seis. Soc. Am., Vol. 99, 585-610. Alarcon, J.E., Franco, G., Bazzurro, P. and Simic, M. (2010). The L’Aquila (Abruzzo) earthquake of 6th April 2009 - Field survey and loss estimation. Proceedings of the $14^{\text {th }}$ European Conference on Earthquake Engineering. Paper 1420.

Alexander, D (2009). Mortaility and Morbidity Risk in the L'Aquila, Italy Earthquake of 6 April 2009 and Lessons to be Learned. Proceedings of the 2nd International Workshop on Disaster Casualties, June 15-16, 2009, Cambridge, UK.

Ameri, G., Augliera, P., Bindi, D., D’Alema, E., Ladina, C., Lovati, S., Luzi, L., Marzorati, S., Massa, M., Pacor, F., and Puglia, R., (2009). Strong-motion parameters of the $\mathrm{Mw}=6.3$ Abruzzo (Central Italy) earthquake, www.mi.ingv.it/docs/report_RAN_20090406.pdf

Beyer K. and Bommer J.J. (2006). Relationships between median values and between aleatory variabilities for different definitions of the horizontal component of motion. Bull. Seis. Soc. Am. 96(4), 1512-1522, Erratum, 97(5), 1769, 2007 Cello, G., Mazzoli, S., Tondi, E. and Turco, E., (1997). Active tectonics in the central Apennines and possible implications for seismic hazard analysis in peninsular Italy, Tectonophysics, 272, 43-68.

De Bruycker, M., Greco, D. and Lechat, M.F. (1985). The 1980 earthquake in southern Italy: mortality and morbidity, International Journal of Epidemiology 14, 113-117. 
De Luca, G., Marcucci, S., Milana, G., and Sanò, T., (2005). Evidence of low-frequency amplification in the city of L'Aquila, Central Italy, through a multidisciplinary approach including strong- and weak-motion data, ambient noise and numerical modeling, Bull. Seis. Soc. Am., 95, 1469-1481.

De Marco R., Martini M.G., Di Pasquale G., Fralleone A., Pizza A.G. and Viola V., (2000). “La classificazione e la normativa sismica Italiana dal 1909 al 1984”. Italian National Seismic Survey Report, Italy.

DM 3.3.75 N.40 (1975). Disposizioni concernenti l'applicazione delle norme tecniche per le costruzioni in zone sismiche. Decreto Ministeriale 3 Marzo 1975 N.40. Published in Gazzetta Ufficiale 8 Aprile 1975, n. 93 - suppl.

DM 24.1.86 (1986). Norme tecniche relative alle costruzioni antisismiche. Decreto Ministero dei Lavori Pubblici 24 Gennaio 1986. Published in Gazzetta Ufficiale 12 Maggio 1986, n. 108.

DM 16.1.96 (1996). Norme tecniche relative alle costruzioni antisismiche. Decreto Ministero LL. PP. 16 Gennaio 1996. Published in Gazzetta Ufficiale 5 Febbraio 1996, n. 29.

EC8 (1998), “Eurocode 8: Design of Structures for Earthquake Resistance”, EN 1998:1, 2003, European Committee of Standardization.

Fralleone A. And Pizza A.G. (2000). Sintesi dei cambiamenti più significativi della normativa italiana per le costruzioni in zone sismiche. Italian National Seismic Survey Report, Italy.

Grünthal, G. (Ed.); 1998. European Macroseismic Scale 1998 (EMS-98). European Seismological Commission, subcommission on Engineering Seismology. Conseil de l’Europe, Cahiers du Centre Européen de Géodynamique et de Séismologie, 15, Luxembourg, 99 pp.

Gruppo Di Lavoro (2003). Normativa tecnica per le costruzioni in zona sismica e connessa classificazione sismica del territorio nazionale: Nota Espicativa dell'Ordinanza del Presidente del Consiglio dei Ministri n. 3274 del 20 marzo 2003 (G.U. n. 105 del 8.5.2003). Istituto Nazionale di Geofisica e Vulcanologia. Milano, Roma.

Gruppo di Lavoro (2004). Redazione della mappa di pericolosita’ sismica, prevista dall’Ordinanza PCM del 20 Marzo 2003, n. 3274. All.1. Rapporto conclusivo per il Dipartimento della Protezione Civile. Istituto Nazionale di Geofisica e Vulcanologia. Milano, Roma, Aprile 2004. 65pp + 5 appendices. 
Hatamizadeh, P., Najafi, I., Vanholder, R., Rashid-Farokhi. F. et al. (2006) Epidemiologic aspects of the Bam earthquake in Iran: the nephrologic perspective, .Am J Kidney Dis.47(3), 428-38.

Henni, P.H.O., Fyfe, C.J., Marrow, P.C. (1998). The BGS World seismicity database. BGS Technical Report no. WL/98/13.

INGV (2009). Istituto Nazionale di Geofisica e Vulcanologia. www.ingv.it. Last accessed 14 August 2009.

Legge 2 Febbraio 1974 .N.64 (1974). Provvedimenti per le costruzioni con particolari prescrizioni per le zone sismiche. Ministero dei Lavori Pubblici, Legge 2 Febbraio 1974, n. 64. Pubblicata nella Gazzetta Ufficiale del 21 marzo 1974, n. 76.

Ordinanza PCM n. 3271 (2003). Primi elementi in materia di criteri generali per la classificazione sismica del territorio nazionale e normative tecniche per le costruzioni in zona sismica. Ordinanza n. 3274 della Presidenza del Consiglio dei Ministri. Published in Supplemento Ord. 72 Gazzetta Ufficiale 8 Maggio 2003, n. 105.

Osaki, Y. and Minowa, M. (2001). Factors Associated with Earthquake Deaths in the Great Hanshin-Awaji Earthquake, 1995, American Journal of Epidemiology, 153(2), 153156.

Pace, B., Boncio, P., and Lavecchia, G., (2002). The 1984 Abruzzo earthquake (Italy): an example of seismogenic process controlled by interaction between differently oriented synkinematic faults, Tectonophysics, 350, 237-254.

Pace, B., Peruzza, L., Lavecchia, G., and Boncio, P., (2006). Layered seismogenic source model and probabilistic seismic-hazard analyses in Central Italy, Bull. Seis. Soc. Am., 96, 107-132.

PreventionWeb (2010):

www.preventionweb.net/english/professional/news/v.php?id=14416. Last accessed $12^{\text {th }}$ August 2010.

Protezione Civile (2009): www.protezionecivile.it . Last accessed 1st September 2009. Romeo, R., and Pugliese, A., 2000. Seismicity, seismotectonics and seismic hazard of Italy, Engineering Geology, 241-266.

Rovida, A., Castelli, V., Camassi, R., and Stucchi, M., (2009). Historical earthquakes in the area affected by the April 2009 seismic sequence, www.mi.ingv.it/eq/090406/storia_eng.html\#evento1461

So, E.K.M (2009). The Assessment of Casualties for Earthquakes Loss Estimation. PhD thesis, Department of Architecture, University of Cambridge, UK. 
Spence, R., D'Ayala, D., Martin, B., Marinescu, J., Sabetta, F., Zuccaro, G. (1998). The Umbria Marche earthquakes of 26 September 1997: a field report by EEFIT, October 1988, 111 pp.

USGS (2006), United States Geological Survey, www.usgs.gov

\section{Web Sources}

Università - L'Aquila Rinasce, 2009. Available at:

http://www.laquilarinasce.org/universita.html [Accessed October 23, 2009].

Tg@bruzzo, 2009. TERREMOTO: CHIODI, A SETTEMBRE APERTE TUTTE LE SCUOLE.tg@bruzzo. Available at: http://tgabruzzo.blogspot.com/2009/07/terremotochiodi-settembre-aperte-tutte.html [Accessed October 23, 2009].

Tgcom, 2009. Sisma L'Aquila, riapre l'ospedale. Available at: http://www.tgcom.mediaset.it/cronaca/articoli/articolo447648.shtml [Accessed October 23, 2009].

YouReporter.it, 2009. Ospedale San Salvatore parzialmente agibile. Available at: http://www.youreporter.it/video_Ospedale_San_Salvatore_parzialmente_agibile_1 [Accessed October 23, 2009]. 
Table 1 Hypocentre and magnitude estimates for the main shock from key reporting agencies

\begin{tabular}{lllllll}
\hline \multirow{2}{*}{ Agency } & Location & & Focal & depth & Magnitude & \\
\cline { 2 - 3 } \cline { 5 - 6 } & Latitude & Longitude & $(\mathrm{km})$ & $\mathrm{M}_{\mathrm{w}}$ & $\mathrm{M}_{\mathrm{L}}$ \\
\hline INGV & 42.33 & 13.33 & 8.8 & 6.2 & 5.8 \\
\hline EMSC & 42.38 & 13.32 & 2.0 & 6.3 & \\
\hline USGS* & 42.423 & 13.395 & 10.0 & 6.3 & \\
\hline
\end{tabular}

Notes: INGV-Instituto Nazionale di Geofisica e Vulcanologia

EMSC - European-Mediterranean Seismological Centre

USGS - United States Geological Survey

* USGS epicentral location as reported after the event. It was changed to that from the INGV. 
Table 2 PGA values recorded by RAN network within $50 \mathrm{~km}$ of the source calculated using the Joyner-Boore $\left(\mathrm{R}_{\mathrm{jb}}\right)$ metric definition (Source PCN) and with ground conditions defined in accordance with EC8 soil type classification system

\begin{tabular}{llllclc}
\hline $\begin{array}{l}\text { Station } \\
\text { Code }\end{array}$ & Province & Lat $\mathbf{N}$ & Lon E & $\begin{array}{c}\text { EC8 Soil } \\
\text { Type }\end{array}$ & PGA (g) & $\begin{array}{c}\mathbf{R}_{\mathbf{j b} \text { distance }} \\
\text { (km) }\end{array}$ \\
\hline AQV & L' Aquila & 42.377 & 13.344 & B & 0.675 & 0 \\
\hline AQG & L' Aquila & 42.373 & 13.337 & B & 0.515 & 0 \\
\hline AQA & L' Aquila & 42.376 & 13.339 & B & 0.487 & 0 \\
\hline AQK & L' Aquila & 42.345 & 13.401 & C & 0.373 & 0 \\
\hline GSA & L' Aquila & 42.421 & 13.519 & A & 0.152 & 9 \\
\hline CLN & L' Aquila & 42.085 & 13.521 & A & 0.091 & 20 \\
\hline AVZ & L' Aquila & 42.027 & 13.426 & C & 0.069 & 25 \\
\hline ORC & L' Aquila & 41.954 & 13.642 & A & 0.066 & 37 \\
\hline MTR & L' Aquila & 42.524 & 13.245 & A & 0.063 & 16 \\
\hline GSG & L' Aquila & 42.460 & 13.550 & A & 0.030 & 14 \\
\hline FMG & Rieti & 42.268 & 13.117 & A & 0.027 & 17 \\
\hline ANT & Rieti & 42.418 & 13.079 & A & 0.026 & 19 \\
\hline CSO1 & L' Aquila & 42.101 & 13.088 & A & 0.019 & 32 \\
\hline LSS & Rieti & 42.558 & 12.969 & A & 0.009 & 36 \\
\hline MMP1 & Rieti & 42.249 & 12.748 & A & 0.009 & 46 \\
\hline
\end{tabular}


Table 3 Summary of building types of different structural types and ages comparing L'Aquila region building stock with national average based on the 2001 ISTAT Census

\begin{tabular}{lcc}
\hline Building Type & $\begin{array}{c}\text { L'Aquila and 13 } \\
\text { neighbouring } \\
\text { municipalities }\end{array}$ & $\begin{array}{c}\text { National } \\
\text { Average }\end{array}$ \\
\hline \% of RC residential buildings & 34 & 29 \\
\hline \% of masonry residential buildings & 66 & 71 \\
\hline \% of post-1981 residential buildings & 19 & 7 \\
\hline
\end{tabular}


Table 4 Building damage survey statistics collected by EEFIT

\begin{tabular}{|c|c|c|c|c|c|c|c|c|c|c|}
\hline \multirow[t]{2}{*}{ Location } & \multirow{2}{*}{$\begin{array}{c}\text { Epicentral } \\
\text { Distance } \\
\text { (km) }\end{array}$} & \multirow[t]{2}{*}{$\begin{array}{c}\text { PGA } \\
\text { (g) }\end{array}$} & \multirow[t]{2}{*}{$\begin{array}{c}\text { Building } \\
\text { Type }\end{array}$} & \multirow[t]{2}{*}{$\begin{array}{l}\text { No. of } \\
\text { Bldgs }\end{array}$} & \multicolumn{6}{|c|}{ EMS 98 Damage State } \\
\hline & & & & & DS0 & DS1 & DS2 & DS3 & DS4 & DS5 \\
\hline \multirow[t]{3}{*}{ Aquila SSE } & \multirow[t]{3}{*}{5.64} & \multirow[t]{3}{*}{0.373} & Masonry & 24 & 13 & 9 & 2 & 0 & 0 & 0 \\
\hline & & & $\begin{array}{l}\text { Strengthened } \\
\text { Masonry }\end{array}$ & 5 & 2 & 3 & 0 & 0 & 0 & 0 \\
\hline & & & RC pre-code & 9 & 3 & 6 & 0 & 0 & 0 & 0 \\
\hline \multirow[t]{2}{*}{ Onna } & \multirow[t]{2}{*}{12.31} & \multirow[t]{2}{*}{$\begin{array}{ll}-- \\
\end{array}$} & Masonry & 41 & 0 & 7 & 1 & 16 & 17 & 0 \\
\hline & & & RC pre-code & 6 & 3 & 1 & 1 & 0 & 0 & 1 \\
\hline \multirow{3}{*}{$\begin{array}{c}\text { San } \\
\text { Gregorio }\end{array}$} & \multirow[t]{3}{*}{13.77} & \multirow[t]{3}{*}{---- } & Masonry & 27 & 6 & 4 & 3 & 3 & 9 & 2 \\
\hline & & & $\begin{array}{l}\text { Strengthened } \\
\text { Masonry }\end{array}$ & 1 & 0 & 0 & 0 & 0 & 1 & 0 \\
\hline & & & RC pre-code & 2 & 0 & 0 & 1 & 0 & 1 & 0 \\
\hline $\begin{array}{l}\text { Poggio } \\
\text { Picenze }\end{array}$ & 17.48 & ---- & Masonry & 42 & 17 & 16 & 5 & 0 & 3 & 1 \\
\hline Barisciano & 21.69 & ---- & Masonry & 13 & 9 & 3 & 1 & 0 & 0 & 0 \\
\hline
\end{tabular}


Table 5 Building fatality survey statistics collected by EEFIT

\begin{tabular}{cccccc}
\hline Location & Fatalities & $\begin{array}{c}\text { Population } \\
\mathbf{( 2 0 0 1 )}\end{array}$ & $\begin{array}{c}\text { Lethality } \\
\mathbf{( \% )}\end{array}$ & $\begin{array}{c}\text { EMS-98 } \\
\text { Intensity }\end{array}$ & $\begin{array}{c}\text { Predominant } \\
\text { type of } \\
\text { Damaged } \\
\text { housing }\end{array}$ \\
\hline L'Aquila & 203 & $\mathbf{7 3 0 0 0}$ & 0.37 & VII & RC, URM \\
\hline Onna & 37 & $400^{*}$ & 9.25 & VIII-IX & URM \\
\hline Villa Sant' Angelo & 17 & 436 & 3.90 & & URM \\
\hline San Gregorio & 8 & $600 *$ & 1.33 & VIII-IX & URM \\
\hline Tempera & 7 & L'Aquila & & VIII & URM \\
\hline Paganica & 5 & L'Aquila & & VIII & URM \\
\hline Poggio Picenze & 5 & 1011 & 0.49 & VIII-IX & URM \\
\hline Barisciano (Castelnuovo) & 5 & 1798 & 0.28 & VI & URM \\
\hline Fossa & 4 & 673 & 0.59 & VII & URM \\
\hline San Demetrio ne' Vestini & 3 & 1605 & 0.19 & VI-VII & URM \\
\hline Civita di Bagno & 1 & L'Aquila & & & URM \\
\hline Pianola & 2 & L'Aquila & & & URM \\
\hline Roio Piano & 2 & L'Aquila & & & URM \\
\hline Tornimparte & 2 & 2958 & 0.07 & & URM \\
\hline Bagno Ripa & 1 & L'Aquila & & URM \\
\hline Poggio di Roio & 1 & L'Aquila & & URM \\
\hline Lucoli & 1 & 944 & 0.11 & URM \\
\hline Cansalessa & 1 & L’Aquila & & & \\
\hline Total & 305 & & & & VII \\
\hline
\end{tabular}

Note: Population census for the L’Aquila municipality includes all communi labeled "L'Aquila” as well as Onna and San Gregorio. In order to deduce the lethality rate as a percentage of population, the reported population of these villages are shown (marked with asterisks) 
